\title{
Long-Term Effects of Feeding Monensin on Milk Fatty Acid Composition in Lactating Dairy Cows
}

\author{
N. E. Odongo, ${ }^{, 1}$ M. M. Or-Rashid, ${ }^{\star}$ R. Bagg, † G. Vessie,† P. Dick,† E. Kebreab, ${ }^{\star}$ J. France, ${ }^{\star}$ \\ and B. W. McBride* \\ *Department of Animal and Poultry Science, University of Guelph, Guelph, Ontario, Canada N1G 2W1 \\ †Elanco Animal Health, Division Eli Lilly Canada Inc., Guelph, Ontario, Canada N1G 4T2
}

\begin{abstract}
The objective of this study was to determine the longterm effects of feeding monensin on milk fatty acid (FA) profile in lactating dairy cows. Twenty-four lactating Holstein dairy cows (1.46 \pm 0.17 parity; $620 \pm 5.9 \mathrm{~kg}$ of live weight; $92.5 \pm 2.62 \mathrm{~d}$ in milk) housed in a tie-stall facility were used in the study. The study was conducted as paired comparisons in a completely randomized block design with repeated measurements in a colorcoded, double blind experiment. The cows were paired by parity and days in milk and allocated to 1 of 2 treatments: 1) the regular milking cow total mixed ration (TMR) with a forage-to-concentrate ratio of 60:40 (control TMR; placebo premix) vs. a medicated TMR [monensin TMR; regular TMR + 24 mg of Rumensin Premix per kg of dry matter (DM)] fed ad libitum. The animals were fed and milked twice daily (feeding at 0830 and $1300 \mathrm{~h}$; milking at 0500 and $1500 \mathrm{~h}$ ). Milk samples were collected before the introduction of treatments and monthly thereafter for 6 mo and analyzed for FA composition. Monensin reduced the percentage of the shortand medium-chain saturated FA 7:0, 9:0, 15:0, and 16:0 in milk fat by $26,35,19$, and $6 \%$, respectively, compared with the control group. Monensin increased the percentage of the long-chain saturated FA in milk fat by $9 \%$, total monounsaturated FA by $5 \%$, total $n-6$ polyunsaturated FA (PUFA) by $19 \%$, total n-3 PUFA by $16 \%$, total cis-18:1 by 7\%, and total conjugated linoleic acid (CLA) by $43 \%$ compared with the control group. Monensin increased the percentage of docosahexaenoic acid (22:6n-3), docosapentaenoic acid (22:5n-3), and cis-9, trans-11 CLA in milk fat by 19,13 , and $43 \%$, respectively, compared with the control. These results suggest that monensin was at least partly effective in inhibiting the biohydrogenation of unsaturated FA in the rumen and consequently increased the percentage of n-6 and
\end{abstract}

Received March 28, 2007.

Accepted July 27, 2007.

${ }^{1}$ Corresponding author: nodongo@uoguelph.ca n-3 PUFA and CLA in milk, thus enhancing the nutritional properties of milk with regard to human health. Key words: monensin, milk fatty acid composition, dairy cow

\section{INTRODUCTION}

Monensin is an ionophore approved for use in lactating dairy cows in several countries, including Australia, Argentina, Brazil, Canada, New Zealand, South Africa, and recently the United States. Monensin is a carboxylic polyether ionophore antibiotic that is produced by fermentation of Streptomyces cinnamonensis (Russell, 2002). Benefits of feeding ionophores to lactating dairy cows include a shift in the acetate-to-propionate ratio toward more propionate and an associated decrease in methanogenesis (Russell and Houlihan, 2003), increased milk production (McGuffey et al., 2001), antiketogenic effects (Duffield and Bagg, 2000), improved BCS (Sauer et al., 1998; Duffield et al., 1999), control of legume bloat (Maas et al., 2002), and reduced risk for acidosis by inhibiting lactic acid production in the rumen (Tung and Kung, 1993; McGuffey et al., 2001).

Odongo et al. (2007) showed that medicating a 60:40 forage-to-concentrate TMR with $24 \mathrm{mg}$ of Rumensin Premix per kilogram of DM was a viable strategy for reducing $\mathrm{CH}_{4}$ production in lactating Holstein dairy cows. Mitigating $\mathrm{CH}_{4}$ emissions from dairy cattle would have long-term environmental benefits in terms of reducing the contribution of animal agriculture to greenhouse gas emissions. However, monensin has also been implicated in milk fat depression (Phipps et al., 2000; McGuffey et al., 2001; Duffield et al., 2003), which has been attributed to reduced ruminal production of acetate and butyrate (Dye et al., 1988; Van der Werf et al., 1998). Monensin inhibits ruminal biohydrogenation of long-chain fatty acids (FA; Fellner et al., 1997) resulting in an accumulation of trans 18:1 FA (Bauman and Griinari, 2003) and the enhanced supply of trans10, cis-12 CLA to the mammary gland (Griinari et al., 1998; Jenkins et al., 2003; Benchaar et al., 2006), which has been shown to be a potent inhibitor of milk fat 
synthesis in dairy cows (Baumgard et al., 2000). Sauer et al. (1998) reported that ruminal microflora in cows that had previously received monensin seemed to undergo some adaptive changes and no longer responded to monensin with repeat monensin supplementation with regard to methane production. However, there is little information on the long-term effects of monensin on ruminal lipid metabolism and milk FA composition. The objective of this study therefore was to determine the long-term effects of feeding monensin on milk FA composition in lactating dairy cows.

\section{MATERIALS AND METHODS}

\section{Animals and Treatments}

Twenty-four lactating Holstein dairy cows (1.46 \pm 0.17 parity; $620 \pm 5.9 \mathrm{~kg}$ of BW; $92.5 \pm 2.62 \mathrm{DIM}$, mean $\pm \mathrm{SE}$ ) housed in a tie-stall facility at the Elora Dairy Research Centre, University of Guelph (Guelph, Ontario, Canada), were used in the study. Animals were cared for and handled in accordance with the Canadian Council on Animal Care regulations, and the University of Guelph Animal Care Committee reviewed and approved the experiment and all procedures carried out in the study. The cows were milked in their stalls twice daily at 0500 and $1500 \mathrm{~h}$. Milk samples from the cows were collected without preservative from morning and afternoon milkings before the introduction of treatments and monthly thereafter for 6 mo and stored at $-20^{\circ} \mathrm{C}$ until analysis.

The study was conducted as paired comparisons in a completely randomized block design with repeated measurements in a color-coded double blind experiment. The experimental procedures have already been described (see Odongo et al., 2007). Briefly, the cows were paired by parity and DIM and allocated to 1 of 2 treatments: 1) the regular Elora Dairy Research Centre milking cow TMR with a forage-to-concentrate ratio of 60:40 introduced at calving (control; placebo premix) or 2) a medicated TMR [monensin; regular TMR + $24 \mathrm{mg}$ of Rumensin Premix (Elanco Animal Health, Division Eli Lilly Canada Inc., Guelph, Ontario, Canada) per kilogram of DM]. The Rumensin Premix was incorporated into soyhulls, which acted as the carrier, whereas the placebo contained only soyhulls. The placebo and monensin premixes were mixed with the TMR each morning. Ingredients and chemical composition of the diet and feeding management were as described by Odongo et al. (2007).

\section{Analysis of FA Composition}

Frozen milk samples were thawed in a $38^{\circ} \mathrm{C}$ water bath and mixed according to method 925.21 (AOAC,
1990). Total milk fat was extracted with chloroform, methanol, and water in the ratio of 1:1:0.9 as described by Bligh and Dyer (1959). The total lipids were methylated using $\mathrm{NaOCH}_{3}$ as catalyst (Cruz-Hernandez et al., 2004) and analyzed directly by GLC. Fatty acid methyl ester analysis was performed using an Agilent 6890N gas-liquid chromatograph (Agilent Technologies, Palo Alto, CA) equipped with a split-splitless injector at $250^{\circ} \mathrm{C}$, a flame-ionization detector at $250^{\circ} \mathrm{C}$, and a CP Sil 88 column $(100 \mathrm{~m}, 0.25 \mathrm{~mm}, 0.2 \mu \mathrm{m}$ film thickness; Varian Inc., Mississauga, Ontario, Canada). Hydrogen was used as carrier gas at a constant flow rate of $1 \mathrm{~mL} /$ min. The temperature of the GLC oven was set to $45^{\circ} \mathrm{C}$ for $4 \mathrm{~min}$, increased at $13^{\circ} \mathrm{C} / \mathrm{min}$ to $175^{\circ} \mathrm{C}$, and held for $27 \mathrm{~min}$, increased at the rate of $4^{\circ} \mathrm{C} / \mathrm{min}$ to a final temperature of $215^{\circ} \mathrm{C}$, and held for $35 \mathrm{~min}$. Agilent Technologies Chemstation software (Rev. B.01.01) was used for data analysis. A 1- $\mu \mathrm{L}$ sample was injected at splitless mode. Peaks were routinely identified by comparison of retention times with FA methyl ester standards (GLC \#463, \#UC-59-M, 21:0, 23:0, and 26:0; Nu-Chek Prep Inc., Elysian, MN). The trans-11, cis-15 18:2 was identified by cross-referencing with previously published isomeric profiles reported for milk fat using cis-9, cis-12 18:2 as a landmark isomer (Ulberth and Henninger, 1994; Precht and Molkentin, 1997). Individual isomers of 18:1 FA were determined as follows: The temperature of GLC oven was maintained at $45^{\circ} \mathrm{C}$ for $4 \mathrm{~min}$, increased to $167^{\circ} \mathrm{C}$ at a rate of $13^{\circ} \mathrm{C} / \mathrm{min}$ and held for $40 \mathrm{~min}$, and again increased at the rate of $4^{\circ} \mathrm{C} /$ min to a final temperature of $218^{\circ} \mathrm{C}$ and held for 23 min. Separation of trans and cis octadecenoic acids was incomplete, but the chromatography allowed the major isomers of interest to be resolved. The trans-6, trans7, and trans-8 18:1 isomers and the trans-13 and trans14 18:1 isomers remained unresolved as single peaks. Individual trans isomers were identified by cross-referencing with previously published isomeric profiles reported for milk fat (Precht and Molkentin, 1997; Shingfield et al., 2003; Loor et al., 2004) using trans-11 18:1 as a landmark isomer. Fatty acid composition was expressed as $\mathrm{g} / 100 \mathrm{~g}$ of total FA.

\section{Statistical Analysis}

The monthly FA measurements were analyzed using the PROC MIXED procedure of SAS (v. 9.1; SAS Inst. Inc., Cary, NC) using the model $\mathrm{Y}_{\mathrm{ijk}}=\mu+\alpha_{\mathrm{i}}+\beta_{\mathrm{j}}+\alpha \beta_{\mathrm{ij}}$ $+\tau_{\mathrm{k}}+\alpha \tau_{\mathrm{ik}}+\varepsilon_{\mathrm{ijk}}$; where $\mathrm{Y}_{\mathrm{ij}}$ is the dependent variable, $\mu$ is the overall mean, $\alpha_{\mathrm{i}}$ is the effect of treatment $\left(_{\mathrm{i}}=1\right.$, $2), \beta_{\mathrm{j}}$ is the effect of pair $(\mathrm{j}=1,2, \ldots, 12), \alpha \beta_{\mathrm{ij}}$ is the effect of a treatment $\times$ pair interaction $\left({ }_{i j}=1,2, \ldots, 24\right)$, $\tau_{\mathrm{k}}$ is the effect of time $(\mathrm{k}=1,2, \ldots, 6), \alpha \tau_{\mathrm{ik}}$ is the effect of treatment $\times$ time interaction $(\mathrm{ik}=1,2, \ldots, 12)$, and 
Table 1. Effects of a control vs. monensin-treated TMR on milk fat fatty acid (FA) contents (g/100 g of FA) in lactating dairy cows

\begin{tabular}{|c|c|c|c|c|c|c|}
\hline \multirow[b]{2}{*}{ Fatty acid ${ }^{1}$} & \multicolumn{2}{|c|}{ TMR } & \multirow[b]{2}{*}{ SEM } & \multicolumn{3}{|c|}{ Time, $P$-value } \\
\hline & Control & Monensin & & Linear & Quadratic & Cubic \\
\hline $6: 0$ & $1.50^{\mathrm{a}}$ & $1.63^{\mathrm{b}}$ & 0.016 & 0.11 & 0.02 & 0.66 \\
\hline $7: 0$ & $0.031^{\mathrm{a}}$ & $0.023^{\mathrm{b}}$ & 0.0014 & 0.02 & 0.15 & 0.01 \\
\hline $8: 0$ & $0.783^{\mathrm{a}}$ & $0.889^{\mathrm{b}}$ & 0.0138 & 0.35 & 0.23 & 0.70 \\
\hline 9:0 & $0.037^{\mathrm{a}}$ & $0.024^{\mathrm{b}}$ & 0.0027 & 0.27 & 0.58 & 0.29 \\
\hline $10: 0$ & 2.35 & 2.43 & 0.044 & 0.40 & 0.17 & 0.46 \\
\hline $11: 0$ & 0.341 & 0.330 & 0.0073 & 0.92 & 0.25 & 0.82 \\
\hline $12: 0$ & 3.09 & 3.01 & 0.044 & 0.02 & 0.07 & 0.52 \\
\hline $12: 1$ & $0.111^{\mathrm{a}}$ & $0.091^{\mathrm{b}}$ & 0.0057 & 0.13 & 0.35 & 0.15 \\
\hline $13: 0$ & 0.089 & 0.088 & 0.0053 & $<0.01$ & 0.30 & $<0.01$ \\
\hline 13:0 iso & 0.026 & 0.024 & 0.0020 & 0.05 & 0.78 & 0.33 \\
\hline 13:0 anteiso & $0.087^{\mathrm{a}}$ & $0.079^{b}$ & 0.0016 & $<0.01$ & 0.73 & 0.06 \\
\hline $14: 0$ & 11.2 & 11.1 & 0.14 & $<0.01$ & 0.19 & 0.71 \\
\hline $14: 0$ iso & 0.082 & 0.083 & 0.0025 & $<0.01$ & 0.78 & 0.04 \\
\hline Cis-9 14:1 & 1.08 & 1.00 & 0.049 & 0.43 & 0.60 & 0.41 \\
\hline $15: 0$ & $1.58^{\mathrm{a}}$ & $1.28^{\mathrm{b}}$ & 0.059 & 0.09 & 0.85 & 0.46 \\
\hline $15: 0$ iso & $0.174^{\mathrm{a}}$ & $0.199^{\mathrm{b}}$ & 0.0027 & 0.20 & 0.01 & 0.61 \\
\hline 15:0 anteiso & 0.438 & 0.451 & 0.0112 & 0.33 & 0.22 & 0.89 \\
\hline $16: 0$ & $33.1^{\mathrm{a}}$ & $30.3^{\mathrm{b}}$ & 0.14 & $<0.01$ & 0.09 & 0.22 \\
\hline $16: 0$ iso & $0.220^{\mathrm{a}}$ & $0.198^{b}$ & 0.0061 & $<0.01$ & 0.51 & 0.11 \\
\hline Trans-9 16:1 & 0.095 & 0.098 & 0.0037 & 0.13 & $<0.01$ & 0.37 \\
\hline Cis-9 16:1 & 1.66 & 1.61 & 0.085 & $<0.01$ & 0.05 & $<0.01$ \\
\hline $17: 0$ & $0.587^{\mathrm{a}}$ & $0.529^{b}$ & 0.0081 & 0.15 & 0.02 & 0.85 \\
\hline $17: 0$ iso & 0.338 & 0.355 & 0.0059 & 0.48 & $<0.01$ & 0.96 \\
\hline 17:0 anteiso & 0.672 & 0.663 & 0.0078 & $<0.01$ & 0.04 & 0.74 \\
\hline $18: 0$ & $10.3^{\mathrm{a}}$ & $11.3^{\mathrm{b}}$ & 0.087 & $<0.01$ & 0.03 & 0.02 \\
\hline $18: 2 n-6$ (LA) & $1.94^{\mathrm{a}}$ & $2.30^{\mathrm{b}}$ & 0.045 & $<0.01$ & 0.73 & 0.06 \\
\hline Trans-9, cis-12 18:2 & 0.041 & 0.046 & 0.0020 & 0.07 & 0.54 & 0.23 \\
\hline Trans-11, cis-15 18:2 & 0.048 & 0.049 & 0.0012 & 0.62 & 0.10 & 0.02 \\
\hline $18: 3 n-6(\gamma \mathrm{LN})$ & 0.033 & 0.024 & 0.0082 & 0.16 & 0.13 & 0.42 \\
\hline $18: 3 n-3(\alpha \mathrm{LN})$ & $0.382^{\mathrm{a}}$ & $0.410^{\mathrm{b}}$ & 0.0083 & $<0.01$ & 0.02 & 0.01 \\
\hline 19:0 & 0.035 & 0.038 & 0.0009 & $<0.01$ & 0.81 & 0.01 \\
\hline $20: 0$ & 0.151 & 0.161 & 0.0036 & $<0.01$ & 0.68 & 0.47 \\
\hline Cis-9 20:1 & $0.152^{\mathrm{a}}$ & $0.165^{\mathrm{b}}$ & 0.0035 & 0.23 & 0.23 & 0.71 \\
\hline Cis-11 20:1 & 0.090 & 0.094 & 0.0015 & 0.10 & 0.01 & 0.18 \\
\hline $20: 2 n-6$ & $0.021^{\mathrm{a}}$ & $0.025^{\mathrm{b}}$ & 0.0008 & $<0.01$ & 0.02 & $<0.01$ \\
\hline $20: 3 n-6$ & $0.078^{\mathrm{a}}$ & $0.096^{\mathrm{b}}$ & 0.0017 & $<0.01$ & 0.83 & $\begin{array}{r}0.41 \\
0.44\end{array}$ \\
\hline $20: 3 n-3$ & 0.008 & 0.009 & 0.0004 & 0.54 & 0.46 & 0.03 \\
\hline $20: 4 n-3$ & $0.032^{\mathrm{a}}$ & $0.036^{\mathrm{b}}$ & 0.0006 & $<0.01$ & 0.39 & 0.61 \\
\hline $20: 4 n-6(\mathrm{AA})$ & 0.116 & 0.143 & 0.0140 & 0.44 & $<0.01$ & 0.15 \\
\hline $20: 5 n-3$ (EPA) & 0.047 & 0.047 & 0.0006 & $<0.01$ & 0.14 & 0.01 \\
\hline $21: 0$ & 0.065 & 0.072 & 0.0133 & $<0.01$ & 0.11 & 0.96 \\
\hline $22: 0$ & 0.060 & 0.066 & 0.0027 & $<0.01$ & 0.93 & 0.92 \\
\hline Cis-13 22:1 & 0.009 & 0.009 & 0.0010 & 0.25 & 0.93 & 0.32 \\
\hline $22: 2 n-6$ & $0.015^{\mathrm{a}}$ & $0.018^{\mathrm{b}}$ & 0.0007 & 0.06 & 0.88 & 0.26 \\
\hline $22: 4 n-6$ & $0.019^{\mathrm{a}}$ & $0.024^{\mathrm{b}}$ & 0.0005 & 0.10 & 0.65 & 0.32 \\
\hline $22: 5 \mathrm{n}-3$ (DPA) & $0.064^{\mathrm{a}}$ & $0.072^{\mathrm{b}}$ & 0.0013 & 0.66 & 0.34 & 0.77 \\
\hline $22: 6 \mathrm{n}-3$ (DHA) & $0.043^{\mathrm{a}}$ & $0.051^{\mathrm{b}}$ & 0.0007 & 0.01 & 0.60 & 0.30 \\
\hline $23: 0$ & 0.026 & 0.026 & 0.0014 & 0.08 & 0.19 & 0.22 \\
\hline $24: 0$ & 0.029 & 0.034 & 0.0017 & $<0.01$ & 0.74 & 0.05 \\
\hline Cis-15 24:1 & $0.007^{\mathrm{a}}$ & $0.006^{\mathrm{b}}$ & 0.0002 & 0.95 & 0.32 & 0.03 \\
\hline $26: 0$ & 0.023 & 0.026 & 0.0009 & $<0.01$ & 0.24 & 0.18 \\
\hline Total CLA ${ }^{2}$ & $0.562^{\mathrm{a}}$ & $0.806^{\mathrm{b}}$ & 0.0138 & $<0.01$ & $<0.01$ & $<0.01$ \\
\hline Total SFA 3 & 64.0 & 64.7 & 0.26 & 0.05 & 0.86 & 0.95 \\
\hline SC_SFA ${ }^{4}$ & $2.36^{\mathrm{a}}$ & $2.56^{\mathrm{b}}$ & 0.020 & 0.09 & 0.03 & 0.82 \\
\hline $\mathrm{MC}^{-} \mathrm{SFA}^{5}$ & 49.4 & 48.9 & 0.22 & $<0.01$ & 0.76 & 0.37 \\
\hline LC_SFA ${ }^{6}$ & $12.3^{\mathrm{a}}$ & $13.3^{\mathrm{b}}$ & 0.09 & $<0.01$ & 0.07 & 0.02 \\
\hline Total MUFA ${ }^{7}$ & $26.0^{\mathrm{a}}$ & $27.4^{\mathrm{b}}$ & 0.22 & 0.07 & 0.74 & 0.56 \\
\hline Total n-6 PUFA ${ }^{8}$ & $2.21^{\mathrm{a}}$ & $2.62^{\mathrm{b}}$ & 0.039 & $<0.01$ & 0.32 & 0.33 \\
\hline Total n-3 PUFA ${ }^{9}$ & $0.51^{\mathrm{a}}$ & $0.59^{\mathrm{b}}$ & 0.010 & $<0.01$ & 0.07 & $<0.01$ \\
\hline
\end{tabular}


Table 1 (Continued). Effects of a control vs. monensin-treated TMR on milk fat fatty acid (FA) contents $(\mathrm{g} / 100 \mathrm{~g}$ of FA) in lactating dairy cows

\begin{tabular}{|c|c|c|c|c|c|c|}
\hline \multirow[b]{2}{*}{ Fatty acid $^{1}$} & \multicolumn{2}{|c|}{ TMR } & \multirow[b]{2}{*}{ SEM } & \multicolumn{3}{|c|}{ Time, $P$-value } \\
\hline & Control & Monensin & & Linear & Quadratic & Cubic \\
\hline n-6:n-3 ratio & $4.74^{\mathrm{a}}$ & $4.51^{\mathrm{b}}$ & 0.073 & $<0.01$ & 0.05 & 0.69 \\
\hline Total trans-18:1 & 4.87 & 4.87 & 0.09 & 0.56 & 0.08 & 0.14 \\
\hline Total cis-18:1 & $21.0^{\mathrm{a}}$ & $22.5^{\mathrm{b}}$ & 0.21 & $<0.01$ & 0.47 & 0.72 \\
\hline
\end{tabular}

${ }^{\mathrm{a}, \mathrm{b}}$ Means within a row with different superscripts differ $(P<0.05)$.

${ }^{1}$ Means of 12 cows per treatment.

${ }^{2}$ Total conjugated linoleic acid (CLA): cis-9, trans-11 18:2; cis-10, trans-12 18:2; trans-9, cis-11 18:2; trans10, cis-12 18:2; trans-11, trans-13 18:2; trans-9, trans-11 18:2; and trans-10, trans-12 18:2.

${ }^{3}$ Total saturated FA (SFA): all FA without any double bond (9:0 to 26:0).

${ }^{4}$ SC_SFA: short-chain SFA (6:0 to 9:0).

${ }^{5}$ MC_SFA: medium-chain SFA (10:0 to 16:0).

${ }^{6}$ LC_SFA: long-chain SFA (17:0 to 26:0).

${ }^{7}$ Total monounsaturated FA (MUFA): all FA with a single double bond (16:1 to 24:1).

${ }^{8}$ Total n-6 polyunsaturated FA (PUFA): trans-9, trans-12 18:2; cis-9, trans-12 18:2; trans-9, cis-12 18:2; $18: 2 \mathrm{n}-6 ; 18: 3 \mathrm{n}-6 ; 20: 2 \mathrm{n}-6 ; 20: 3 \mathrm{n}-6 ; 22: 2 \mathrm{n}-6$; and $22: 5 \mathrm{n}-6$.

${ }^{9}$ Total n-3 PUFA: 18:3n-3; 20:3n-3; 20:4n-3; and 22:4n-3.

$\varepsilon_{\mathrm{ij}}$ is the random residual error. Pretreatment milk fat content (total) was used as a covariate, and the repeated measurement option in time was used with cow nested within pair by treatment as the repeat subject. Firstorder autoregressive covariance model was fitted to the data. To determine time-dependent changes and interactions between time and treatment, the effects of control vs. monensin over time were evaluated using orthogonal contrasts. Effects were considered significant at a probability of $P<0.05$, and data are expressed as mean \pm standard error of the mean, which represents the pooled standard error for the model.

\section{RESULTS AND DISCUSSION}

Results of the DMI, milk yield, milk composition, and $\mathrm{CH}_{4}$ production have already been published (see Odongo et al., 2007). Briefly, monensin had no effect on the DMI and milk yield of the cows. Monensin reduced $\mathrm{CH}_{4}$ production by $7 \%$ (expressed as $\mathrm{g} / \mathrm{d}$ ) and by $9 \%$ (expressed as $\mathrm{g} / \mathrm{kg}$ of $\mathrm{BW}$ ), which were sustained for 6 mo (mean, 458.7 vs. $428.7 \pm 7.75 \mathrm{~g} / \mathrm{d}$ and 0.738 vs. $0.675 \pm 0.0141$, control vs. monensin, respectively). Monensin reduced milk fat percentage by $9 \%$ (3.90 vs. $3.53 \pm 0.098 \%$, control vs. monensin, respectively) and milk protein by $4 \%$ (3.37 vs. $3.23 \pm 0.031 \%$, control vs. monensin, respectively). Methane production per kilogram of milk and milk protein percentage increased linearly with time, DMI presented cubically with time, and milk yield declined linearly with time. Time had no effect on milk fat percentage (Odongo et al., 2007).

Milk fat FA, 18:1 isomers, and CLA contents (g/100 $\mathrm{g}$ of total FA) are summarized in Tables 1, 2, and 3. Short-chain saturated FA (SFA) increased quadrati- cally $(P<0.05)$ over the course of the trial, whereas total and medium-chain SFA increased linearly $(P<$ 0.05 ; Table 1). Long-chain SFA presented cubically ( $P$ $<0.05)$ over the course of the trial. The percentage of the short- and medium-chain SFA 7:0, 9:0, 15:0, and 16:0 in the milk fat of monensin-treated cows were 26, 35,19 , and $6 \%$ lower $(P<0.05)$, respectively, than in the control group, which is consistent with the results of Sauer et al. (1998). The percentage of 6:0 and 8:0 in the monensin group were 9 and $14 \%$ higher $(P<0.05)$, respectively, than in the control group. Fatty acids in milk arise from 2 sources, uptake from circulation and de novo synthesis within the mammary epithelial cells (Bauman and Davis, 1974; Dils, 1986; Neville and Picciano, 1997). Short-chain (4:0 to 9:0) and medium-chain (10:0 to 16:0) FA arise almost exclusively from de novo synthesis, whereas long-chain (>16:0) FA are derived from the uptake of circulating lipids. Palmitic acid (16:0) originates from both de novo synthesis and uptake from circulating lipids (Mansbridge and Blake, 1997).

There were no treatment differences $(P>0.05)$ in the total short-chain and medium-chain SFA (Table 1). The percentage of most odd- and branched-chain FA (7:0, 9:0, 11:0, 13:0, 13:0 iso, 13:0 ai, 15:0 and 16:0 iso) in the short- and medium-chain SFA group were lower $(P$ $<0.05)$ for the monensin group than for the control group. Because odd- and branched-chain FA are synthesized by chain elongation of VFA in the rumen (Garton, 1977; Or-Rashid et al., 2007), monensin supplementation might have changed the proportions of VFA production by altering the biochemical activities of some of the rumen microbes (Dye et al., 1988). The percentage of even-chain SFA in the medium-chain range (e.g., 
Table 2. Effects of a control vs. monensin-treated TMR on milk fat $18: 1$ isomers ( $\mathrm{g} / 100 \mathrm{~g}$ of fatty acids) in lactating dairy cows

\begin{tabular}{lcccccc}
\hline & \multicolumn{2}{c}{ TMR } & & \multicolumn{3}{c}{ Time, $P$-value } \\
\cline { 2 - 3 } Fatty acid $^{1}$ & Control & Monensin & SEM & Linear & Quadratic & Cubic \\
\hline Trans-4 18:1 & 0.018 & 0.020 & 0.0009 & 0.62 & 0.12 & 0.14 \\
Trans-5 18:1 & 0.013 & 0.014 & 0.0006 & 0.22 & 0.99 & 0.39 \\
Trans-6-8 18:1 & 0.398 & 0.388 & 0.0061 & 0.29 & 0.89 & 0.67 \\
Trans-9 18:1 & 0.618 & 0.635 & 0.0115 & 0.54 & 0.16 & 0.35 \\
Trans-10 18:1 & $0.985^{\mathrm{a}}$ & $0.758^{\mathrm{b}}$ & 0.0322 & $<0.01$ & 0.58 & 0.03 \\
Trans-11 18:1 & $1.21^{\mathrm{a}}$ & $1.41^{\mathrm{b}}$ & 0.035 & $<0.01$ & $<0.01$ & 0.47 \\
Trans-12 18:1 & 0.525 & 0.550 & 0.0200 & 0.39 & 0.24 & 0.80 \\
Trans-13-14 18:1 & 0.883 & 0.871 & 0.0303 & 0.46 & 0.57 & 0.33 \\
Trans-16 18:1 & 0.214 & 0.222 & 0.0074 & 0.42 & 0.24 & 0.71 \\
Cis-9 18:1 & $19.3^{\mathrm{a}}$ & $20.6^{\mathrm{b}}$ & 0.22 & $<0.01$ & 0.43 & 0.87 \\
Cis-11 18:1 & $1.33^{\mathrm{a}}$ & $1.47^{\mathrm{b}}$ & 0.025 & 0.64 & 0.74 & 0.35 \\
Cis-12 18:1 & $0.407^{\mathrm{a}}$ & $0.460^{\mathrm{b}}$ & 0.0093 & 0.81 & 0.25 & 0.10 \\
Cis-13 18:1 & 0.045 & 0.054 & 0.0035 & $<0.01$ & 0.59 & 0.84 \\
\hline
\end{tabular}

${ }^{\mathrm{a}, \mathrm{b}}$ Means within a row with different superscripts differ $(P<0.05)$.

${ }^{1}$ Means of 12 cows per treatment.

12:0, 14:0, and 16:0) was also lower for the monensin treatment, likely, at least in part, due to reduced ruminal production and supply of acetate and butyrate as reported by Van der Werf et al. (1998). The increased proportion of trans-9, cis-11 CLA with the monensin treatment might also have been involved to decrease the de novo synthesis of the medium-chain, even-chain SFA in mammary gland. The possible role of trans -9 , cis-11 CLA is discussed below. The percentages of 12:1, $14: 1$, and 16:1 were also numerically lower with the monensin treatment compared with the control treatment (Table 1), which might at least in part be due to decreased activities of $\Delta^{9}$-desaturase in body tissues.

The percentage of the long-chain SFA in the milk fat of monensin-treated cows was $9 \%$ higher $(P<0.05)$ than in the control group (Table 1). This increase in longchain SFA was primarily due to stearic acid. It is generally accepted that ionophores, such as monensin, nigericin, and tetronasin are effective in partially inhibiting the biohydrogenation of linoleic acid thus reducing the rate of stearic acid production (Fellner et al., 1997). Feeding ionophores inhibit the last step of biohydrogenation because they increase rumen outflow of trans 18:1 FA and reduce the outflow of stearic acid (Bauman and Griinari, 2003). The higher percentage of 18:0 with the monensin treatment in the present study cannot, however, be explained solely by the inhibitory action of the ionophore on the biohydrogenation of $18: 2 \mathrm{n} 6$. Ionophores also act by inhibiting lipolysis as described below.

Total n-6 PUFA and total n-3 PUFA were 19 and $16 \%$ higher $(P<0.05)$, respectively, in the monensin group than in the control group (Table 1 ). Total n-3 PUFA presented cubically $(P<0.05)$ over the course of the trial, the n-6:n-3 ratio increased quadratically $(P<$
$0.05)$, whereas total n-6 PUFA reduced linearly $(P<$ 0.05 ) over the course of the trial (Table 1 ). The monensin treatment had a lower n-6 PUFA to n-3 PUFA ratio than the control $(P<0.01$, Table 1$)$. Monensin increased $(P<0.05)$ the percentage of $18: 2 \mathrm{n}-6,18: 3 \mathrm{n}-3$, cis-9 20:1, $20: 2 n-6,20: 3 n-6,20: 4 n-3,22: 2 n-6,22: 4 n-6,22: 5 n-3$, and $22: 6 \mathrm{n}-3$ compared with the control group. Monensin increased the percentage of docosahexaenoic acid (22:6n-3) linearly by $19 \%$ over the course of the trial and docosapentaenoic acid (22:5n-3) by $13 \%$. Time had no $(P>0.05)$ effect on the percentage of docosapentaenoic acid in total FA (Table 1). $\alpha$-Linolenic acid (18:3n3 ) constituted the majority of total n-3 FA measured, and its proportions were higher $(P<0.05)$ with the monensin treatment, which increased cubically $(P<$ 0.05 ) over the course of the trial. The potential benefits associated with increased intake of n-3 PUFA in human diets have been described (e.g., Knapp et al., 2003).

Total monounsaturated FA (MUFA) were $5 \%$ higher $(P<0.05)$ in the monensin group than in the control group (Table 1). Time had no $(P>0.05)$ effect on total MUFA (Table 1). The 18:1 isomers in milk are presented in Table 2. Trans-10 18:1 presented cubically $(P<0.05)$ over the course of the trial, trans-11 18:1 increased quadratically $(P<0.05)$, whereas cis-9 $18: 1$ and cis-13 18:1 increased linearly $(P<0.05)$ over the course of the trial (Table 2). Time had no $(P>0.05)$ effect on trans4 18:1, trans-5 18:1, trans-6-8 18:1, and trans-9 18:1 percentage (Table 2). The ratio of total cis-18:1 to total trans-18:1 in both treatments was approximately 5:1 in agreement with the FA profile reported by Sauer et al. (1998). Total cis-18:1 were $7 \%$ higher $(P<0.05)$ in the monensin group than in the control group. The percentage of $c i s-9$ 18:1 was highest among the MUFA in both groups and was $7 \%$ higher $(P<0.05)$ in the monen- 
Table 3. Conjugated linoleic acid contents ( $\mathrm{g} / 100 \mathrm{~g}$ of fatty acid) in the milk fat of lactating dairy cows fed a control vs. monensin-treated TMR

\begin{tabular}{|c|c|c|c|c|c|c|}
\hline \multirow[b]{2}{*}{ Fatty acid $^{1}$} & \multicolumn{2}{|c|}{ TMR } & \multirow[b]{2}{*}{ SEM } & \multicolumn{3}{|c|}{ Time, $P$-value } \\
\hline & Control & Monensin & & Linear & Quadratic & Cubic \\
\hline Cis-9, trans-11 CLA & $0.462^{\mathrm{a}}$ & $0.662^{\mathrm{b}}$ & 0.0144 & $<0.01$ & $<0.01$ & 0.06 \\
\hline Trans-9, cis-11 CLA & 0.052 & 0.060 & 0.0097 & 0.01 & 0.42 & $<0.01$ \\
\hline Trans-10, cis-12 CLA & 0.014 & 0.014 & 0.0005 & 0.67 & 0.29 & 0.04 \\
\hline Trans-11, trans-13 CLA & 0.031 & 0.031 & 0.0023 & 0.12 & 0.30 & 0.81 \\
\hline Trans -9, trans $-11+$ trans -10, trans -12 CLA & 0.037 & 0.037 & 0.0016 & $<0.01$ & 0.50 & 0.97 \\
\hline
\end{tabular}

${ }^{\mathrm{a}, \mathrm{b}}$ Means within a row with different superscripts differ $(P<0.05)$.

${ }^{1}$ Means of 12 cows per treatment.

sin treatment than in the control group. The higher proportion of cis-9 18:1 in the milk of monensin treatment cows, at least in part, may suggest that monensin partially inhibited cis-9 18:1 from microbial biohydrogenation. According to Van Nevel and Demeyer (1995), ionophores and other antimicrobials act primarily to inhibit lipolysis, thus reducing the formation of free carboxyl groups that are required for subsequent hydrogenation of double bonds. Cis-11 18:1, cis-12 18:1, and trans-11 18:1 (vaccenic acid) were higher $(P<0.05)$ in the milk of cows on the monensin treatment by 11 , 13 , and $17 \%$, respectively, than in the control group. Vaccenic acid was the main trans-18:1 isomer comprising 25 vs. $29 \%$ of total trans-18:1 in the milk of the control and monensin treatment groups, respectively. An increased flow of trans-11 18:1 from the rumen is desirable because it would result in increased cis-9, trans-11 CLA in the milk because trans-11 18:1 is converted to cis-9, trans-11 CLA in the mammary gland and other tissues catalyzed by $\Delta^{9}$-desaturase (Bauman and Griinari, 2003). Additionally, Turpeinen et al. (2002) reported that on average $19 \%$ of dietary trans11 18:1 was converted to cis-9, trans-11 CLA in humans.

Trans-10 18:1 in the monensin treatment was $23 \%$ lower $(P<0.05)$ than in the control group (Table 2$)$. Firkins et al. (2006) has suggested that because Megasphaera elsdenii are not sensitive to physiological doses of monensin (Rychlik et al., 2002) unlike Butyrivibrio fibrisolvens (Nagaraja et al., 1997; Callaway et al., 1999), addition of monensin to dairy rations might increase fluxing of unsaturated FA through trans-10 intermediates. Although an increased percentage of trans-10 18:1 in milk has been associated with decreased milk fat content (Griinari et al., 1998; Bauman and Griinari, 2003), the results of the current study (data from the monensin-treated group) does not support this. Consistent with Lock et al. (2007) who infused pure trans-10 18:1 in the abomasum of dairy cows and reported that although trans-10 18:1 was taken up by the mammary gland and transferred to milk fat, it had no effect on milk fat synthesis even when provided at a dose 10 times greater than the effective dose of trans10, cis-12 CLA. The results of the current study are also consistent with previous studies where changes in trans-10, cis-12 CLA contents in diet-induced milk fat depression were not adequate to explain the reduction in milk fat, suggesting that additional biohydrogenation intermediates may also have been involved in the regulation of milk fat synthesis (Bauman and Griinari, 2003). For example trans-9, cis-11 CLA was higher for the monensin treatment than for the control treatment (Table 3). Perfield et al. (2007) has suggested that an increase in milk fat content of trans-9, cis-11 CLA was also associated with diet-induced milk fat depression. These authors provided evidence of a role for this isomer in milk fat depression based on the $15 \%$ reduction in milk fat yield with abomasal infusion of CLA enrichment isomers ( $32 \%$ trans -9 , cis- $11,29 \%$ cis- 9 , trans- 11 , and $17 \%$ trans -9 , trans-11) that supplied $5 \mathrm{~g} / \mathrm{d}$ of trans9, cis-11 CLA. Furthermore, Jenkins et al. (2003) reported that addition of $25 \mathrm{mg} / \mathrm{kg}$ of monensin in continuous cultures of ruminal bacteria increased the concentration of trans-10 18:1 but had no effect on the concentration of trans-11 18:1 in contrast to the results in the current study. The percentage of total trans 18:1 and other 18:1 isomers in milk in the current study were not $(P>0.05)$ affected by dietary treatment.

Milk fat CLA contents are presented in Table 3. Total, trans-9, cis-11, and trans-10, cis-12 CLA presented cubically $(P<0.05)$ over the course of the trial; cis-9, trans11 CLA increased quadratically $(P<0.05)$, whereas trans-9, trans-11 + trans-10, trans-12 CLA increased linearly $(P<0.05)$ over the course of the trial (Tables 1 and 3). Time had no $(P>0.05)$ effect on trans-11, trans-13 CLA percentage (Table 3). Monensin increased $(P<0.05)$ total CLA content in the milk by $43 \%$ compared with the control group, suggesting that the nutritional properties of milk had been enhanced. Sauer et al. (1998) observed a significant increase in CLA in milk from 0.8 to $1.3 \%$ of milk fat with monensin treatment. However, other studies (e.g., Chouinard et al., 1998; Dhiman et al., 1999) have not shown a beneficial effect 
of ionophores for enriching the concentration of CLA in milk fat. Recently, a wealth of literature available mainly from cell line and animal studies indicates that CLA and individual isomers (cis-9, trans-11 and trans10, cis-12) may have numerous health benefits including effects on body composition, specifically a reduction in body fat mass, anticarcinogenic, antiatherogenic, antidiabetogenic, and immune modulating effects (e.g., Ip et al., 1999; Lock and Bauman, 2004; Bhattacharya et al., 2006). Nutritional strategies that increase CLA content in milk using diet formulation and nutritional management of dairy cows are therefore desirable.

The most abundant CLA in the current study was cis-9, trans-11 CLA, which constituted 76 to $82 \%$ of the total CLA content (Table 3). Monensin increased $(P<$ 0.05) cis-9, trans-11 CLA in milk by $43 \%$ compared with the control group. Fellner et al. (1997) observed higher concentrations of trans 18:1, and CLA in continuous cultures of ruminal bacteria following infusion of ionophores monensin, migericin, or tetronasin. Ruminal microorganisms capable of FA hydrogenation are often divided into groups A (e.g., B. fibrisolvens, Ruminococcus albus, and Eubacterium spp.) and B (e.g., Fusocillus spp. and R8/5 gram-negative road) based on their products and patterns of isomerization during biohydrogenation (Harfoot and Hazlewood, 1988). Bacterial species in group A hydrogenate linoleic acid to trans-18:1 but appear incapable of hydrogenating mononenes. Group $B$ bacteria on the other hand can hydrogenate a wide range of monenes to stearic acid, including trans-11 18:1. Although monensin is known as an inhibitor of gram-positive bacteria (e.g., B. fibrisolvens; Van Nevel and Demeyer, 1995), it seems from the current study that monensin might also inhibit the activities of group $\mathrm{B}$ bacteria, responsible for the last step of biohydrogenation of 18:2n6 to 18:0. Consequently, more CLA and trans-11 18:1 escaped biohydrogenation, thus resulting in higher levels of CLA and trans-11 18:1 in the milk fat. Butyrivibrio fibrisolvens has been shown to synthesize mainly cis-9, trans-11 CLA from 18:2n6 (Kepler et al., 1966; Kim et al., 2000). The percentage of trans-9, cis11 CLA, trans-10, cis-12 CLA, trans-11, trans-13 CLA and trans-9, trans-11 plus trans-10, trans-12 CLA in milk were not $(P>0.05)$ affected by dietary treatment. It has been suggested that only a small amount of cis9, trans-11 CLA actually accumulates in the rumen and that the majority of milk CLA is derived from trans11 18:1 in the mammary gland through the somatic desaturation action of $\Delta^{9}$-desaturase (Griinari et al., 2000). The relatively constant ratio between cis-9, trans-11 CLA and trans-11 18:1 in both treatments supports the concept that much of the trans-11 18:1 was converted to CLA endogenously by $\Delta^{9}$-desaturase. Sauer et al. (1998) had reported that ruminal microflora in cows that had previously received monensin seemed to have undergone some adaptive changes and no longer responded to monensin with repeat monensin supplementation. The result of the current study does not support this and are consistent with Odongo et al. (2007).

\section{CONCLUSIONS}

Monensin increased the percentage of docosahexaenoic acid (22:6n-3) in milk by $19 \%$, docosapentaenoic acid (22:5n-3) by $13 \%$, and cis-9, trans-11 and total CLA by $43 \%$ compared with the control group. These results suggest that monensin was at least partly effective in inhibiting the biohydrogenation of unsaturated FA in the rumen and consequently increased the percentage of total PUFA, MUFA, and CLA in milk, thus enhancing the nutritional properties of the milk in terms of human health.

\section{ACKNOWLEDGMENTS}

The authors thank Laura Wright and the staff at the Elora Dairy Research Centre, University of Guelph for their technical assistance and Elanco Animal Health, Division Eli Lilly Canada Inc. for financial support. We also acknowledge the continued support received from the Ontario Ministry of Agriculture, Food and Rural Affairs, and the Natural Sciences and Engineering Research Council of Canada (BWM).

\section{REFERENCES}

AOAC. 1990. Official Methods of Analysis. 15th ed. AOAC, Arlington, VA.

Bauman, D. E., and C. L. Davis. 1974. Biosynthesis of milk fat. Pages 31-75 in Lactation: A Comprehensive Treatise. Vol. 2. B. L. Larson, V. R. Smith, ed. Academic Press, New York, NY.

Bauman, D. E., and J. M. Griinari. 2003. Nutritional regulation of milk fat synthesis. Annu. Rev. Nutr. 23:203-227.

Baumgard, L. H., B. A. Corl, D. A. Dwyer, A. Saebo, and D. E. Bauman. 2000. Identification of the conjugated linoleic acid isomer that inhibits milk fat synthesis. Am. J. Physiol. 278:R179-R184.

Benchaar, C., H. V. Petit, R. Berthiaume, T. D. Whyte, and P. Y. Chouinard. 2006. Effects of addition of essential oils and monensin premix on digestion, ruminal fermentation, milk production, and milk composition in dairy cows. J. Dairy Sci. 89:4352-4364.

Bhattacharya, A., J. Banu, M. Rahman, J. Causey, and G. Fernandes. 2006. Biological effects of conjugated linoleic acids in health and disease. J. Nutr. Biochem. 17:789-810.

Bligh, E. G., and W. J. Dyer. 1959. A rapid method of total lipid extraction and purification. Can. J. Biochem. Physiol. 37:911-917.

Callaway, T. R., K. A. Adams, and J. B. Russell. 1999. The ability of "low G + C Gram-positive" ruminal bacteria to resist monensin and counteract potassium depletion. Curr. Microbiol. 39:226-230.

Chouinard, P. Y., L. Corneau, L. M. Kelly, J. M. Griinari, and D. E. Bauman. 1998. Effect of dietary manipulation on milk conjugated linoleic acid concentrations. J. Dairy Sci. 81(Suppl.1):233. (Abstr.)

Cruz-Hernandez, C., Z. Deng, J. Zhou, A. R. Hill, M. P. Yurawecz, P. Delmonte, M. M. Mossoba, M. E. R. Dugan, and J. K. G. Kramer. 2004. Methods for analysis of conjugated linoleic acids and 
trans 18:1 isomers in dairy fats by using a combination of gas chromatography, silver-ion thin-layer chromatography/gas chromatography, and silver-ion liquid chromatography. J. AOAC Int. $87: 545-562$.

Dhiman, T. R., G. R. Anand, L. D. Satter, and M. W. Pariza. 1999. Conjugated linoleic acid content of milk from cows fed different diets. J. Dairy Sci. 82:2146-2156.

Dils, R. R. 1986. Comparative aspects of milk fat synthesis. J. Dairy Sci. 69:904-910.

Duffield, T. F., and R. Bagg. 2000. Use of ionophores in lactating dairy cattle: A review. Can. Vet. J. 41:388-394.

Duffield, T. F., S. LeBlanc, R. Bagg, K. Leslie, J. Ten Hag, and P. Dick. 2003. Effect of a monensin controlled release capsule on metabolic parameters in transition dairy cows. J. Dairy Sci. $86: 1171-1176$.

Duffield, T. F., D. Sandals, K. E. Leslie, K. Lissemore, B. W. McBride, J. H. Lumsden, P. Dick, and R. Bagg. 1999. Effect of prepartum administration of a monensin controlled release capsule on milk production and milk components in early lactation. J. Dairy Sci. 82:272-279.

Dye, B. E., H. E. Amos, and M. A. Froetschel. 1988. Influence of lasalocid on rumen metabolites, milk production, milk composition and digestibility in lactating cows. Nutr. Rep. Int. 38:101115.

Fellner, V., F. D. Sauer, and J. K. G. Kramer. 1997. Effect of nigericin, monensin, and tetronasin on biohydrogenation in continuous flow-through ruminal fermenters. J. Dairy Sci. 80:921-928.

Firkins, J. L., A. N. Hristov, M. B. Hall, G. A. Varga, and N. R. StPierre. 2006. Integration of ruminal metabolism in dairy cattle. J. Dairy Sci. 89:E31-E51.

Garton, G. A. 1977. Fatty acid metabolism in ruminants. Page 337 370 in Biochemistry of Lipids II. T. W. Goodwin, ed. University Park Press, Baltimore, MD.

Griinari, J. M., B. A. Corl, S. H. Lacy, P. Y. Chouinard, K. V. V. Nurmela, and D. E. Bauman. 2000. Conjugated linoleic acid is synthesized endogenously in lactating cows by $\Delta-9$ desaturase. J. Nutr. 130:2285-2291.

Griinari, J. M., D. A. Dwyer, M. A. McGuire, D. E. Bauman, D. L. Palmquist, and K. V. V. Nurmela. 1998. Trans-octadecenoic acids and milk fat depression in lactating dairy cows. J. Dairy Sci. 81:1251-1261.

Harfoot, C. G., and G. P. Hazlewood. 1988. Lipid metabolism in the rumen. Page 285 in The Rumen Microbial Ecosystem. P. N. Hobson, ed. Elsevier Sci. Publ., London, UK.

Ip, C., S. Banni, E. Angioni, G. Carta, J. McGinley, H. J. Thompson, D. Barbano, and D. Bauman. 1999. Conjugated linoleic acid-enriched butterfat alters mammary gland morphogenesis and reduces cancer risk in rats. J. Nutr. 129:2135-2142.

Jenkins, T. C., V. Fellner, and R. K. McGuffey. 2003. Monensin by fat interactions on trans fatty acids in cultures of mixed ruminal microorganisms grown in continuous fermentors fed corn or barley. J. Dairy Sci. 86:324-330.

Kepler, C. R., K. P. Hiron, J. J. McNeill, and S. B. Tove. 1966. Intermediates and products of the biohydrogenation of linoleic acid by Butyrivibrio fibrisolvens. J. Biol. Chem. 241:1350-1354.

Kim, Y. J., R. H. Liu, D. R. Bond, and J. B. Russell. 2000. Effect of linoleic acid concentration on conjugated linoleic acid production by Butyrivibrio fibrisolvens A38. Appl. Environ. Microbiol. 66:5226-5230.

Knapp, H. R., N. Salem, and S. Cunnane. 2003. Dietary Fats and Health. Proceedings of the 5th International Congress of the Society of Fatty Acids and Lipids (ISSFAL). Lipids 38:297-496.

Lock, A. L., and D. E. Bauman. 2004. Modifying milk fat composition of dairy cows to enhance fatty acids beneficial to human health. Lipids 39:1197-1206.

Lock, A. L., C. Tyburczy, D. A. Dwyer, K. J. Harvatine, F. Destaillats, Z. Mouloungui, L. Candy, and D. E. Bauman. 2007. Trans-10 octadecenoic acid does not reduce milk fat synthesis in dairy cows. J. Nutr. 137:71-76.
Loor, J. J., K. Ueda, A. Ferlay, Y. Chilliard, and M. Doreau. 2004. Biohydrogenation, duodenal flow, and intestinal digestibility of trans fatty acids and conjugated linoleic acids in response to dietary forage: Concentrate ratio and linseed oil in dairy cows. J. Dairy Sci. 87:2472-2485.

Maas, J. A., S. N. McCutcheon, G. F. Wilson, G. A. Lynch, M. E. Hunt, and L. A. Crompton. 2002. Effect of monensin sodium on lactational performance of autumn- and spring-calving cows. J. Dairy Res. 69:317-323.

Mansbridge, R. J., and J. S. Blake. 1997. Nutritional factors affecting the fatty acid composition of bovine milk. Br. J. Nutr. 78(Suppl. 1):S37-S47.

McGuffey, R. K., L. F. Richardson, and J. D. Wilkinson. 2001. Ionophores for dairy cattle: Current status and future outlook. J. Dairy Sci. 84(E Suppl.):E194-E203.

Nagaraja, T. G., C. J. Newbold, C. J. Van Nevel, and D. I. Demeyer. 1997. Manipulation of rumen fermentation. Pages 523-632 in The Rumen Microbial Ecosystem. P. N. Hobson and C. S. Stewart, ed. Chapman and Hall, London, UK.

Neville, M. C., and M. F. Picciano. 1997. Regulation of milk lipid secretion and composition. Annu. Rev. Nutr. 17:159-184.

Odongo, N. E., R. Bagg, G. Vessie, P. Dick, M. M. Or-Rashid, S. E. Hook, J. T. Gray, E. Kebreab, J. France, and B. W. McBride. 2007. Long-term effects of feeding monensin on methane production in lactating dairy cows. J. Dairy Sci. 90:1781-1788.

Or-Rashid, M., N. E. Odongo, and B. W. McBride. 2007. Fatty acid composition of ruminal bacteria and protozoa, with emphasis on conjugated linoleic acid, vaccenic acid, and odd-chain and branched-chain fatty acids. J. Anim. Sci. 85:1228-1234.

Perfield, J. W., II, A. L. Lock, J. M. Griinari, A. Sæbø, P. Delmonte, D. A. Dwyer, and D. E. Bauman. 2007. Trans-9, cis-11 conjugated linoleic acid reduces milk fat synthesis in lactating dairy cows. J. Dairy Sci. 90:2211-2218.

Phipps, R. H., J. I. D. Wilkinson, L. J. Jonker, M. Tarrant, A. K. Jones, and A. Hodge. 2000. Effect of monensin on milk production of Holstein-Friesian dairy cows. J. Dairy Sci. 83:2789-2794.

Precht, D., and J. Molkentin. 1997. Trans-geometric and positional isomers of linoleic acid including conjugated linoleic acid (CLA) in German milk and vegetables fats. Lipids 99:319-326.

Russell, J. B. 2002. Rumen microbiology and its role in ruminant nutrition. James B. Russell, Cornell University Press, Ithaca, NY.

Russell, J. B., and A. J. Houlihan. 2003. The ionophore resistance ruminal bacteria and its potential impact on human health. FEMS Microbiol. Rev. 27:65-74.

Rychlik, J. L., R. LaVera, and J. B. Russell. 2002. Amino acid deamination by ruminal Megasphaera elsdenii strains. Curr. Microbiol. 45:340-345.

Sauer, F. D., V. Fellner, R. Kinsman, J. K. G. Kramer, H. A. Jackson, A. J. Lee, and S. Chen. 1998. Methane output and lactation response in Holstein cattle with monensin or unsaturated fat added to the diet. J. Anim. Sci. 76:906-914.

Shingfield, K. J., S. Ahvenjrvi, V. Toivonen, A. Ärölä, K. V. V. Nurmela, P. Huhtanen, and J. M. Griinari. 2003. Effect of fish oil on biohydrogenation of fatty acids and milk fatty acid content in cows. Anim. Sci. 77:165-179.

Tung, R. S., and L. Kung, Jr. 1993. In vitro effects of a thiopeptide and monensin on ruminal fermentation of soluble carbohydrates. J. Dairy Sci. 76:1083-1090.

Turpeinen, A. M., M. Mutanen, A. Antti, I. Salminen, S. Basu, D. L. Palmquist, and J. M. Griinari. 2002. Bioconversion of vaccenic acid to conjugated linoleic acid in humans. Am. J. Clin. Nutr. 75:504-510.

Ulberth, F., and M. Henninger. 1994. Quantitation of trans fatty acids in milk fat using spectroscopic and chromatographic methods. J. Dairy Res. 61:517-527.

Van der Werf, J. H. L., L. J. Jonker, and K. Oldenbroek. 1998. Effect of monensin on milk production by Holstein and Jersey cows. J. Dairy Sci. 81:427-433.

Van Nevel, C., and D. I. Demeyer. 1995. Lipolysis and biohydrogenation of soybean oil in the rumen in vitro: Inhibition by antimicrobials. J. Dairy Sci. 78:2797-2806. 